\author{
Ощепков О.П. \\ кандидат економічних наук, доцент \\ кафедра обліку та аудиту \\ E-mail: moto47rod@gmail.com \\ Магденко C.O. \\ старший викладач \\ кафедра економіки промисловості \\ Одеська національна академія харчових технологій \\ вул. Канатна, 112, м. Одеса, Україна, 65039 \\ E-mail: maglana1@meta.ua
}

\title{
ФОРМУВАННЯ ПЕРЕДУМОВ ЕКСПОРТНОЇ СТРАТЕГІЇ РОЗВИТКУ ПІДПРИЄМСТВ АГРОПРОДОВОЛЬЧОГО КОМПЛЕКСУ УКРАЇНИ
}

В статті розглядаються питання розвитку підприємств агропродовольчого комплексу, та визначення передумов розробки експортної стратегії подальшого їх розвитку. На підставі дослідження різних понять і підходів до фрормування стратегій розвитку, авторами надано власна трактовка до передумов формування експортної стратегії. Це виділення ресурсної стратегії, техніко-технологічної та соціально-економічної стратегій, які відображають розвиток підприємства як складної соціальноекономічної системи.

Стратегія - це сукупність фрорм, методів і способів організації довгострокових напрямів діяльності з реалізації мети або місії підприємства. В процесі розробки стратегії важливо враховувати вплив зовнішніх і внутрішніх фракторів, неврахування яких може привести до ризику втрати значних ресурсів. Тому значна увага має приділятися таким аспектам, як: хто буде реалізовувати експортну стратегію та рівень його компетенції, ступінь державної підтримки підприємств в частині отримання інвестицій та впровадження інновацій, здатність підприємств забезпечувати конкурентні переваги за рахунок якості та безпеки експортної продукції.

Ключові слова: агропродовольчий комплекс, підприємство, стратегія, експортна стратегія, розвиток, експорт, державне регулювання.

This work is licensed under a Creative Commons Attribution 4.0 International License http://creativecommons.org/licenses/by/4.0/

Постановка проблеми та її зв'язок з важливими науковими та практичними завданнями. Україна займає провідне місце в реалізації продукції рослинного походження на світовому ринку. Проте, сучасні тенденції розвитку економіки України все більш потребують від підприємств виробництва готової експортноорієтованої продукції. Експорт продукції дозволить підприємствам зайняти відповідну частку сегменту світового ринку та підвищити ефективність своєї діяльності.

Разом $з$ тим, підвищення ефективності функціонування і розвитку експортної стратегії підприємств агропродовольчого комплексу об'єктивно обумовлено низкою факторів:

- по-перше, це зростання конкуренції на внутрішньому і зовнішньому ринку, поглиблення міжнародного розподілу праці, інтернаціоналізація та глобалізація економіки; ба за них;

- по-друге, це обмеженість ресурсів і бороть-

- по-третє, обмеженість споживчого попиту в країні і боротьба за гривню споживача.

Все вищезазначене свідчить про те, що тема $€$ актуальною і потребує подальшого розгляду, а також вимагає прийняття конкретних рішень як на законодавчому рівні, так і виконання цих рішень на мікро- $\mathrm{i}$ макрорівні.

Аналіз останніх публікацій по проблемі. Питання формування стратегії розвитку як на рівні макроекономіки, так і на мікрорівні призначено багато праць як іноземних, так і вітчизняних авторів. Разом 3 тим, в роботах приділялась увага окремим напрямкам і концепціям стратегії взагалі. Найбільш відомі автори праць: І.Ансофф [1], Г.Мінцберг [2], М.Портер, Р.Румельт [3], Ж.Мілан, А.Маршалл, серед вітчизняних - це О.Амоша, П.Гайдуцький, В.Кошельнік, Л.Михайлова, О.Павлов, Ю.Погорелов, П.Саблук та інш. Узагальнену характеристику різних напрямів стратегій розвитку наведено в роботі М.С.Крочака [4]. Основні передумови розробки експортної стратегії в якості засад концепції стійкого розвитку розглядаються в роботі В.С. Чуєшової [5]. Разом 3 тим, в розглянутих концепціях не враховується соціально-економічний стан в той чи іншій країни, тим більш специфіка галузі, до якої належить певне підприємство. Галузеві аспекти розвитку підприємств 
досліджено в роботах Н.Купріної, Т.Дудки, К.Козак, В.Шаленого, О.Петренка та інш. Аналіз стратегії розвитку агропродовольчого комплексу розглянуто в роботах О.П.Антонюка, О.А.Гальцевої, Т.Ю.Салькової. Разом з тим, в роботах названих авторів недостатньо проводиться дослідження підприємства як системи, яка має інтегровану структуру, не розкрито можливості і стимули до експортних стратегій розвитку виробництва і реалізації продукції.

Формування цілей дослідження. Метою дослідження $є$ теоретико-методичні підходи до визначення орієнтирів та передумов експортної стратегії розвитку підприємств агропродовольчого комплексу як складних соціально-економічних систем в сучасних умовах.

Виклад основних результатів та їх обгрунтування. Існують різні підходи до характеристики стратегій, їх сутності, взаємозв'язку стратегії розвитку зі стратегіями економічного зростання. Сутність стратегії розвитку підприємства полягає в тому, що за допомогою сукупності форм, методів і принципів дій досягнуто прийняття ефективних рішень діяльності підприємства в довгостроковій перспективі. Румельт Р. в своїх роботах зазначає, що «стратегія є набором послідовних аналітичних заходів, концепцій, методів, аргументів та дій, що покликані знайти таке рішення проблеми, яке дозволить серйозно вплинути на ситуацію та виправити їі» [3, с.18]. Разом 3 тим, автор не виділяє часовий період, тому таке поняття можна віднести і до тактики дій, яка є формою або етапом стратегічних рішень і дій.

Розглядаючи процес розвитку, Р.Ансофф визначає, що «розвиток - це питання не стільки того, що є, скільки того, що може бути зроблено з тим, що €» $[4$, c.306].

На нашу думку, всі стратегії можна поділити на соціально-економічні, техніко-технологічні і ресурсні, які будуть формувати модель стратегічного розвитку підприємства. Тільки після всебічного вивчення цих різних стратегій, можна будувати та запроваджувати нові моделі розвитку підприємства як складної соціально-економічної системи, в тому числі, й експортну стратегію його розвитку.

Такий підхід, вважає О.І.Кондратюк, дозволяє розглядати розвиток як процес структурних змін у соціально-економічній системі підприємства, який спрямований на його перехід до нового соціальноекономічного стану у часі під впливом факторів внутрішнього і зовнішнього середовища [6].

В процесі розробки певної стратегії, як зазначає I.M.Агєєва, передбачені окремі процедури [7]:

- розробка бажаного стану підприємства;

- визначення мети, місії;

- визначення конкретних заходів досягнення мети з урахуванням сильних і слабких сторін, враховуючи можливі ризики.

Формування експортної стратегії тісно пов'язано з експортним потенціалом підприємства та його складом. Нами обраний ресурсний підхід до визначення експортного потенціалу.

Іншими словами, експортна стратегія, на на- шу думку, має визначати:

- що експортувати (яку саме продукцію);

- кому експортувати (в яку країну);

- скільки експортувати (обсяг і номенклатуру продукції) та за якою ціною.

Експортна стратегія - це комплексний план 3 експортної діяльності підприємства, заснованої на його експортному потенціалі і спрямованої на реалізацію конкурентоспроможної продукції на зовнішньому ринку.

Розглянемо елементи системи підприємства, які характеризують назви зазначених вище груп стратегій. Ресурсна стратегія включає: трудові ресурси (професійний склад і рівень кваліфікації, ступень забезпеченості кадрами та їх плинність), матеріальні ресурси (сировина, натуральні і синтетичні матеріали, енергоресурси), фінансові ресурсі (власні, залучені).

Техніко-технологічна стратегія характеризує стан основних засобів (наявність, придатність, моральний і фізичний знос основних засобів, їх оновлення), ступінь впровадження досягнень НТП та сучасних технологій (виробничих, інноваційних, організаційних, інформаційних).

Соціально-економічні стратегії характеризують: організацію (форми і методи виробництва, форми організації і оплати праці, соціально побутові умови); планування (оперативне, поточне, стратегічне), управління (вибір методів управління виходячи із організаційно-економічної системи підприємства, механізм погодження економічних інтересів всіх структурних підрозділів та їх працівників). Тобто, як зазначає В.І. Корольов, при розробці стратегії розвитку важливо визначити, хто буде реалізовувати цю стратегію, які компетенції, яка система комунікацій і яка система оцінки роботи персоналу [8, с. 55-56].

Характеристика експортної стратегії розвитку підприємств АПК залежить від внутрішніх і зовнішніх факторів, які склались на момент іiі формування і тенденцій їх розвитку в майбутньому.

В залежності від специфіки діяльності підприємства і виду продукції, що виробляється, розглядаються різні експортні стратегії:

- диференціації;

- лідерства;

- фокусування.

Ми вважаємо, що для підприємств АПК найбільш характерною є експортна стратегія диференціації, яка потребує розробки продуктової політики, цінової політики та політики просування і дистрибуції на зовнішній ринок.

Зараз експортна стратегія розвитку підприємства, в більшості, залежить від зовнішніх факторів, до яких можна віднести наступні:

- політична нестабільність і соціальна напруга в суспільстві;

- монополізм на енергоресурси, який диктує власні умови, не враховуючи соціальні інтереси суспільства;

- нестабільність податкового законодавства;

- високі ставки по кредитам, які не стимулюють інвестиції; 
- бюрократична система отримання дозволу на експортні операції.

Перераховані зовнішні фактори характеризують, що формування експортної стратегії розвитку підприємств України здійснюється в умовах невизначеності та може привести до ризиків значних втрат підприємства. Тому більшість підприємств не мають довгострокових стратегій, а більш діють тимчасовими рішеннями, що також обумовлює підприємства не впроваджувати інноваційні стратегії, які безпосередньо пов'язані з інвестиціями, вартість яких висока. Також більшість підприємств збиткові або низькорентабельні, не мають власних оборотних коштів, що є загрозою низької їх ліквідності і платоспроможності.

Нами досліджено, що вищезазначені зовнішні та внутрішні фактори, які впливають на розробку експортної стратегії підприємств, характерні для більшості підприємств харчової промисловості України: вони мусять працювати в умовах нестабільності та політичної і соціальної кризи [9, с.70-74].

Аналіз структури і динаміки експорту підприємств агропродовольчого комплексу досліджується в роботах О.П.Антонюка [10] та інших авторів.

Наведемо динаміку експорту продукції АПК України в табл.1 та за їі даними розрахуємо структуру експорту (табл. 2).

Таблиця 1

Динаміка обсягів експорту продукції АПК України в 2010-2017 роках, млн. дол. США*

\begin{tabular}{|l|c|c|c|c|c|c|c|c|}
\hline \multirow{2}{*}{ Продукція } & \multicolumn{7}{c|}{ роки } \\
\cline { 2 - 10 } & 2010 & 2011 & 2012 & 2013 & 2014 & 2015 & 2016 & 2017 \\
\hline Тваринного походження & 771,4 & 936,6 & 961,3 & 1084,1 & 1014,5 & 823,4 & 775,0 & 1109,0 \\
\hline Рослинного походження & 3976,3 & 5532,0 & 9213,9 & 8875,9 & 8736,1 & 7971,5 & 8093,7 & 9216,4 \\
\hline $\begin{array}{l}\text { Олії та жири тваринного } \\
\text { або рослинного походження }\end{array}$ & 2617,3 & 3396,4 & 4211,5 & 3507,1 & 3822,0 & 3299,8 & 3963,0 & 4605,7 \\
\hline Готові харчові продукти & 2571,1 & 2939,1 & 3493,9 & 3557,2 & 3096,3 & 2468,4 & 2450,1 & 2827,3 \\
\hline Всього & 9936,1 & 12804,1 & 17880,6 & 17024,3 & 16669,0 & 14563,1 & 15281,8 & 17758,4 \\
\hline
\end{tabular}

Таблиця 2

Структура експорту продукції АПК України в 2010-2017 роках, у відсотках*

\begin{tabular}{|l|c|c|c|c|c|c|c|c|}
\hline \multicolumn{1}{|c|}{ Продукція } & \multicolumn{9}{c|}{ роки } \\
\cline { 2 - 10 } & 2010 & 2011 & 2012 & 2013 & 2014 & 2015 & 2016 & 2017 \\
\hline Тваринного походження & 7,76 & 7,31 & 5,38 & 6,37 & 6,09 & 5,65 & 5,07 & 6,24 \\
\hline Рослинного походження & 40,02 & 43,20 & 51,53 & 52,14 & 52,41 & 54,74 & 52,96 & 51,90 \\
\hline $\begin{array}{l}\text { Олії та жири тваринного або } \\
\text { рослинного походження }\end{array}$ & 26,34 & 26,53 & 23,55 & 20,60 & 22,93 & 22,66 & 25,93 & 25,94 \\
\hline Готові харчові продукти & 25,88 & 22,95 & 19,54 & 20,89 & 18,58 & 16,95 & 16,03 & 15,92 \\
\hline Всього & 100,00 & 100,00 & 100,00 & 100,00 & 100,00 & 100,00 & 100,00 & 100,00 \\
\hline
\end{tabular}

*Розраховано авторами за даними табл.1

За даними табл. 2 можна зробити висновок, що найбільшу питому вагу в експорті продукції АПК займає продукції рослинного походження - майже половина всього експорту.

По продукції тваринного походження протягом 2010-2016 років спостерігається поступове зменшення питомої ваги в загальному обсязі експорту (з 7,76 до 5,07 відсотків). В 2017 році питома вага декілька збільшилася та становила 6,24 відсотки.

По продукції рослинного походження протягом 2010-2017 років спостерігається поступове зростання питомої ваги в загальному обсязі експорту (з 40,02 до 51,90 відсотків). Найбільша питома вага становила в 2015 році - 54,74 відсотки.

По оліям та жирам спостерігається незначне коливання - 3 26,34 до 25,94 відсотків (в 2010 році та 2017 році відповідно). Найменша питома вага становила 20,60 відсотків в 2013 році.

Проте, по готовим харчовим продуктам спостерігається суттєве зниження питомої ваги - 3 25,88 відсотків в 2010 році до 15,92 відсотків в 2017 році.
Пріоритетним напрямом експортної стратегії підприємств України має стати експорт не сировини (продукції рослинного походження), а готової продукції з високою доданою вартістю. Це потребує комплексного рішення низки питань як з боку самих підприємств, так і з боку держави.

Новим етапом для розвитку підприємств АПК було прийняття Програми експортної стратегії Мінагрополітики на 2017-2021 роки, в якій були визначені їі головні вектори:

1. Орієнтація на малий і середній бізнес

2. Нарощування обсягів експорту

3. Відкриття нових ринків

4. Якість і безпека продукції [12].

Висновки та перспективи подальшого дослідження. Реалізація визначеної експортної стратегії розвитку України, в тому числі агропродовольчого комплексу, потребує нових підходів, які повинні спиратись на інтенсивність, інвестиційність і інноваційність.

Експортна стратегія розвитку підприємств АПК може ефективно функціонувати і розвиватись в 
Україні при формуванні певних мотиваційних, економічних, організаційних, правових та соціальних умов, які дають однакову можливість здійснювати експортні операції малому, середньому і великому бізнесу. Це - механізми державної фінансової підтримки, податкової, інформаційно-консультативної, маркетингової та інших видів підтримки, в тому числі, й дипломатичної.
Разом $з$ тим, на теперішній час, вихід на зовнішній ринок для більшості підприємств АПК - це використання стратегії непрямого експорту, тобто реалізації продукції через інші фірми, незалежних посередників та фірми, бренд яких вже відомий.

Подальшого дослідження потребує розробка експортної стратегії для підприємств окремих галузей з урахуванням їхньої специфіки функціонування.

\title{
Література
}

1. Ансофф И. Стратегическое управление / И. Ансофф; пер. с англ. Л.И. Евенко. Москва: Экономика, 1989. 519 с. (рус. яз.)

2. Минцберг Г., Альстренд Б., Лэмпел Дж. Школы стратегий / Г.Минцберг; пер. с англ. под ред. Ю.Н. Каптуревского. СПб: Издательство “Питер”, 2000. 336 с. (рус.яз.)

3. Румельт Р. Хорошая стратегия, плохая стратегия. В чем отличие и почему это важно / Ричард Румельт; пер.с англ. О.Медведь. Москва: Манн, Иванов и Фербер, 2014. 448 с. (рус.яз.)

4. Крочак М.С. Формування стратегії розвитку промислових підприємств в умовах невизначеності // Науковий вісник Мукачівського університету. Сер. Економіка. 2017. Вип. 1(17). C.83-89. URL: http://www.msu.edu.ua/visn/?p=2698\&lang=uk дата звернення 30.05.2018

5. Чуешова В.С. Национальная экспортная стратегия как ключ устойчивости // Экономика и предпринимательство. 2017. № 2-2(79). С.160-163

6. Кондратюк О.І. Основні напрямки економічного розвитку підприємств в сучасних умовах // Наук. пр. / Таврійський державний агротехнологічний університет (економічні науки). 2013. №1(1). C. 257-266. URL: http://nbuv.gov.ua/UJRN/znptdau_2013_1_1_33 (дата звернення 3.08.2018)

7.Агеєва I.М., Агаркова О.В. Дослідження стратегії розвитку на підприємствах виноробної галузі // Економіка харчової промисловості. 2017. Вип.4. С.35 - 42; DOI: 10.15673/fie.v9i4.741

8. Королёв В.И. Разработка экспортной стратегии компании //Российский внешнеэкономический вестник. 2015. № 11. С.54-65

9. Ощепков О.П., Магденко С.О. Економічні аспекти розвитку підприємств харчової промисловості України // Тенденції розвитку аграрного сектору економіки України в умовах соціально-економічної та політичної нестабільності: матеріали наук. колокв., Одеса, 15 трав. 2015 р. / Одеська національна академія харчових технологій. Одеса, 2015. С.70-74

10. Антонюк О.П., Антонюк П.О., Лисюк В.М. Аналіз динаміки та структури експорту агропродовольчої продукції // Економіка харчової промисловості. 2017. Вип. 3. C.8-15; DOI: 10.15673/fie.v10i2.957

11. Державна служба статистики України: [Веб-сайт]. Київ, 2018. URL: http://www.ukrstat.gov.ua (дата звернення 28.05.2018)

12. Про схвалення експортної стратегії України («дорожньої карти» стратегічного розвитку торгівлі) на 2017-2021 роки: розпор. кабінету міністрів України від 27.12.2017 p. № 1017-p. URL: https://www.kmu.gov.ua/ua/npas/pro-shvalennya-eksportnoyi-strategiyi-ukrayini-dorozhnoyi-karti-strategichnogorozvitku-torgivli-na-20172021-roki (дата звернення 30.05.2018)

Стаття надійшла 10.08.2018 Стаття прийнята до друку 24.08.2018 Доступно в мережі Internet 17.10.2018

\author{
Ощепков А.П. \\ кандидат экономических наук, доцент \\ кафедра учёта и аудита \\ E-mail: moto47rod@gmail.com \\ Магденко С.A. \\ старший преподаватель \\ кафедра экономики промышленности \\ Одесская национальная академия пищевых технологий \\ ул. Канатная, 112, г. Одесса, Украина,65039 \\ E-mail: maglana1@meta.ua
}

\section{ФОРМИРОВАНИЕ УСЛОВИЙ ЭКСПОРТНОЙ СТРАТЕГИИ РАЗВИТИЯ ПРЕДПРИЯТИЙ АГРОПРОДОВОЛЬСТВЕННОГО КОМПЛЕКСА УКРАИНЫ}

В работе рассматриваются актуальные вопросы формирования условий для разработки экспортной стратеги развития предприятий агропродовольственого комплекса Украины. Рассмотрено 
понятие стратегии как долгосрочной перспективы деятельности предприятия, направленной на реализацию цели или его миссии с помощью различных способов, форм и методов. В процессе исследования экспортной стратегии развития предприятий использованы научные разработки и точки зрения различных авторов, которые характеризуют ту или иную сторону экспортной стратегии.

Любая стратегия может развиваться при определенных условиях, которые сложились на данном этапе функционирования предприятия под влиянием внутренних и внешних факторов. Авторы считают, что все стратегии можно поделить на блоки стратегий, реализация которых будет основой для разработки единой экспортной стратегии развития предприятия. Выделяют социальноэкономическую, технико-технологическую и ресурсную стратегии развития предприятия.

Социально-экономическая стратегия включает в себя вопросы организации, оплаты и стимулирования труда с целью согласования экономических интересов всех структурных подразделений предприятия и работников. Здесь обосновывается, кто будет непосредственно реализовывать экспортную стратегию, каков уровень компетенций, ответственности и заинтересованности в реализации поставленной цели предприятия.

Технико-технологическая стратегия должна способствовать производить на предприятии качественную, ресурсосберегающую и безопасную продукцию для потребителя.

Ресурсная стратегия отражает наличие трудовых ресурсов, их профессиональный и квалификационный уровень, материальных и финансовых ресурсов.

Для реализации экспортной стратегии важное место занимает и государственная поддержка предприятий, без которой их эффективное развитие невозможно. Для осуществления такой поддержки авторы предлагают ряд предложений, реализация которых позволит решить данную проблему. Особое место отводится переходу на инновационный тип развития, используя доступные кредиты и инвестиции.

Ключевые слова: агропродовольственный комплекс, предприятие, стратегия, экспортная стратегия, развитие, экспорт, государственное регулирование.

Oshchepkov 0.

Ph.D., Associate Professor

Department of Accounting and Auditing

E-mail: moto47rod@gmail.com

Magdenko S.

Assistant

Department of Industrial Economics

Odessa National Academy of Food Technologies

Kanatna str., 112, Odessa, Ukraine, 65039

E-mail:maglana1@meta.ua

\section{FORMATION OF EXPORT STRATEGY CONDITIONS FOR DEVELOPMENT OF ENTERPRISES OF THE AGRO-FOOD COMPLEX OF UKRAINE}

In this article current issues of formation of the conditions for the working out of an export strategy for the development of enterprises of the agro-food complex of Ukraine have been considered. The concept of the strategy as a long-term perspective of the enterprise's activities aimed at realizing the goal or its mission through various ways, forms and methods has been considered. In the process of researching of the export strategy of the enterprise development, scientific developments and views of various authors that characterize one or another side of the export strategy have been used.

Any strategy can be developed under certain conditions that have developed at this stage of the enterprise's functioning under the influence of internal and external factors. The authors believe that all strategies can be divided into blocks of strategies, the implementation of which will be the basis for the working out of a single export strategy of the enterprise development. Socio-economic, technical and technological and resource development strategies of the enterprise have been distinguished.

The socio-economic strategy includes the issues of organizing, paying and stimulating labor in order to harmonize the economic interests of all structural divisions of the enterprise and its employees. It has been justified who will directly implement the export strategy, is the level of competence, responsibility and interest in the implementation of the stated goal of the enterprise has been determined.

Technical and technological strategy should help to produce high-quality, resource-saving and safe products for the consumer. 
The resource strategy reflects the availability of labor resources, their professional and qualification level, material and financial resources.

To implement the export strategy, the important place is taken by state support of enterprises, without which their effective development is impossible. To implement such support, the authors offer a number of proposals, the implementation of which will solve this problem. A special place is given to the transition to an innovative type of development, using available loans and investments. regulation

Key words: agro-food complex, enterprise, strategy, export strategy, development, export, state

\section{References}

1. Ansoff, I. (1989). Strategicheskoe upravlenie (L. I. Evenko, Trans.). Moskva: Ekonomika.

2. Mintsberg, G., Alstrend, B., \& Lempel, Dzh. (2000). Shkolyi strategiy (Yu. N. Kapturevskiy, Trans.). SPb.: Izdatelstvo "Piter".

3. Rumelt, R. (2014). Horoshaya strategiya, plohaya strategiya. V chem otlichie i pochemu eto vazhno (O. Medved, Trans.). Moskva: Mann, Ivanov i Ferber.

4. Krochak, M. S. (2017). Formuvannia stratehii rozvytku promyslovykh pidpryiemstv v umovakh nevyznachenosti. Naukovyi Visnyk Mukachivskoho Universytetu, (1 (17)), ekonomika, 83-89. Retrieved May 30, 2018, from http://www.msu.edu.ua/visn/?p=2698\&lang=uk

5. Chueshova, V. S. (2017). Natsionalnaya eksportnaya strategiya kak klyuch ustoychivosti. Ekonomika I Predprinimatelstvo, (2-2 (79)), 160-163.

6. Kondratiuk, O. I. (2013). Osnovni napriamky ekonomichnoho rozvytku pidpryiemstv v suchasnykh umovakh. Zbirnyk Naukovykh Prats Tavriiskoho Derzhavnoho Ahrotekhnolohichnoho Universytetu (ekonomichni Nauky), (1 (1)), 257-266. Retrieved August 30, 2018, from http://nbuv.gov.ua/UJRN/znptdau_2013_1_1_33

7. Aheieva, I. M., \& Aharkova, O. V. (2017). Doslidzhennia stratehii rozvytku na pidpryiemstvakh vynorobnoi haluzi. Ekonomika Kharchovoi Promyslovosti,(4), 35-42. doi:10.15673/fie.v9i4.741

8. KorolYov, V. I. (2015). Razrabotka eksportnoy strategii kompanii. Rossiyskiy Vneshneekonomicheskiy Vestnik, (11), 54-65.

9. Oshchepkov, O. P., \& Mahdenko, S. O. (2015). Ekonomichni aspekty rozvytku pidpryiemstv kharchovoi promyslovosti Ukrainy. In Tendentsii rozvytku ahrarnoho sektoru ekonomiky Ukrainy $v$ umovakh sotsialnoekonomichnoi ta politychnoi nestabilnosti (pp. 70-74). Odesa: Odeska natsionalna akademiia kharchovykh tekhnolohii.

10. Antoniuk, O. P., Antoniuk, P. O., \& Lysiuk, V. M. (2017). Analiz dynamiky ta struktury eksportu ahroprodovolchoi produktsii. Ekonomika Kharchovoi Promyslovosti, (3), 8-15. doi:10.15673/fie.v10i2.957

11. Derzhavna sluzhba statystyky Ukrainy. (2018). Retrieved May 28, 2018, from http://www.ukrstat.gov.ua

12. Pro skhvalennia eksportnoi stratehii Ukrainy: Rozpor. kabinetu ministriv Ukrainy vid 27.12.2017 r. № 1017-r. («dorozhnoi karty» stratehichnoho rozvytku torhivli) na 2017-2021 roky. (2017). Retrieved May 30, 2018, from https://www.kmu.gov.ua/ua/npas/pro-shvalennya-eksportnoyi-strategiyi-ukrayini-dorozhnoyi-karti-strategichnogorozvitku-torgivli-na-20172021-roki

Received 10 August 2018 Approved 24 August 2018 Available in Internet 17.10.2018

Цитування згідно ДСТУ 8302:2015

Ощепков О.П., Магденко С.О.Формування передумов експортної стратегії розвитку підприємств агропродовольчого комплексу України // Економіка харчової промисловості. 2018. Т. 10, Вип. 3. С. 21-26; doi: 10.15673/fie.v10i3.1057

Cite as APA style citation

Oshchepkov, O., \& Magdenko, S. (2018). Formation of export strategy conditions for development of enterprises of the agro-food complex of Ukraine. Food Industry Economics, 10(3), 21-26; doi: 10.15673/fie.v10i3.1057 